\title{
Overview of SARS-CoV-2 Outbreak and Potential Therapeutic Strategies
}

\author{
Othman A. Eldalal ${ }^{1,2}$, Oladayo A. Oyebanji ${ }^{1}$, Pariksha Thapa ${ }^{1} \&$ Terry L Oroszi ${ }^{1}$ \\ ${ }^{1}$ Department of Pharmacology and Toxicology, Boonshoft School of Medicine, Wright State University, Dayton, \\ Ohio, USA \\ ${ }^{2}$ Department of Drug Technology, Faculty of Medical Technology, Derna, Libya \\ Correspondence: Othman A. Eldalal, School of Medicine, Wright State University, Dayton, Ohio, 45435, USA. \\ Tel: 1-206-371-7337. E-mail: othmanaldellal@yahoo.com/eldalal.2@wright.edu
}

Received: August 18, 2020 Accepted: October 28, 2020 Online Published: November 11, 2020

doi:10.5539/gjhs.v12n13p95 URL: https://doi.org/10.5539/gjhs.v12n13p95

\begin{abstract}
The increasing severity of the ongoing COVID-19 pandemic, caused by the severe acute respiratory syndrome coronavirus 2 (SARS-CoV-2), remains an urgent global issue to be addressed. Despite several heroic and concerted efforts, morbidity and mortality continue to increase. Providing a therapeutic respite in the form of an effective antiviral agent and, potentially, a vaccine remains an uphill task. The SARS-CoV-2 is an enveloped positive-sense single-stranded RNA virus, with an unusual potential for rapid reproduction and mutation, transmitted majorly through aerosols. The virus replicates in the mucosa of the upper respiratory tract, which accounts for its early symptoms. Multiple organs can be affected and can also be asymptomatic. SARS-CoV-2 has genomic similitude to the SARS-CoV and MERS-CoV viruses, being members of the same family, Betacoronaviridae. These similarities have been explored as potential therapeutic targets. Developing a drug at a pandemic speed usually involves initial drug repurposing strategies, and the ongoing pandemic has not been an exception. With notable recruitments ranging from the old antimalarial agent, Chloroquine/Hydroxychloroquine, to the macrolide Azithromycin, to ACE inhibitors, to antiviral agents like Lopinavir/Ritonavir and more recently, the RNA polymerase inhibitor, Remdesivir, the search is still ongoing. Sourcing from highly reputable reports and studies conducted so far, this review elaborates on the biology of the SARS-CoV-2 virus, highlighting its structure, shared genetic similarities and variants, with respect to being potential therapeutic targets, as well as a commentary on the therapeutic approaches that have been explored in the quest to develop an effective antiviral agent.
\end{abstract}

Keywords: COVID-19, 2019 novel coronavirus disease, SARS-CoV-2, Betacoronaviridae, ACE2, SARS-CoV-2's structure, Life cycle, ACE2, Clinical outcomes, Physiopathology, Immunopathology, Genomic diversity, Management strategies

\section{Introduction}

The ongoing coronavirus outbreak, coronavirus disease 2019 (COVID-19), which was pronounced a pandemic via the World Health Organization (WHO) on June 18, 2020, has infected more than 8 million individuals and caused approximately 400,000 deaths in over 188 countries ("Coronavirus Disease (COVID-19) Situation Reports," n.d.). The novel coronavirus, known as severe acute respiratory syndrome coronavirus 2 (SARS-CoV-2), belongs to the family $\beta$ - coronaviridae, responsible for the respiratory disease associated with the 2002-2003 outbreak (SARS-CoV-1) (Fehr \& Perlman, 2015).

SARS-CoV-2 is an enveloped positive-sense single-stranded RNA virus, characterized by quick reproduction and shows markedly high potential to mutate with subsequent generation (Pachetti et al., 2020a). Phylogenetically, it is linked to severe acute respiratory syndrome-like (SARS-like) bat viruses (Zhou et al., 2020) with a variety of potential intermediate hosts such as pangolins, but not mice and rats (Peters, Vetter, Guitart, Lotfinejad, \& Pittet, 2020).

Virus transmission happens by direct (placed on persons) or indirect (placed on objects) contact and airborne (Kutter, Spronken, Fraaij, Fouchier, \& Herfst, 2018). Recent reports indicate that transmission is possible by person-to-person contact, respiratory droplet, prospectively in fecal-oral routes (Wei et al., 2020; Yeo, Kaushal, \& Yeo, 2020) in addition to the likelihood of aerosol transmission (Van Doremalen et al., 2020). The viral replication 
is thought to occur in the mucosal epithelium of the upper respiratory tract such as nasal cavity and pharynx, with additional multiplicity in the lower respiratory tract as well as gastrointestinal mucosa (Xiao et al., 2020), giving rise to a mild viremia. The recent estimate of the mean incubation period for SARS-CoV-2 is 6.4 days, varying from 2.1 days to 11.1 days ( 2.5 to 97.5 percentile), with a possible asymptomatic transmission (Backer, Klinkenberg, \& Wallinga, 2020). Some patients have been known to exhibit non-respiratory symptoms such as acute liver and heart injury, kidney failure, diarrhea (Y. Cheng et al., 2020; Guan et al., 2020; Huang et al., 2020a; D. Wang et al., 2020) implying multiple organ involvement. Lately, a possible testicular involvement has been reported, implying possible fertility implications in adolescent patients (Fan, Li, Ding, Lu, \& Wang, 2020).

Clinical studies showed that the commonest factors influencing the mortality rate are advanced age and pre-existing disease (Jin et al., 2020). Patients with cardiovascular (CV) risk factors such as advanced age, diabetes, male sex, high blood pressure, and obesity, in addition to patients with established CV and cerebrovascular disease, have been noted as susceptible people with increased morbidity and mortality when infected with SARS-CoV-2 ("ESC Guidance for the Diagnosis and Management of CV Disease during the COVID-19 Pandemic," n.d.).

To date, the pathogenesis of SARS-CoV-2 infection in individuals or the precise ways of host immune reaction in preventing the threat of this virus to human beings are still unclear. The mortality, as well as morbidity of COVID-19 disease, are extensively different ranging from asymptomatic, moderate to lethal. Importantly, it has been found that children are likely to be protected from deadly serious cases, whereas, aging and immunocompromised adults are highly impacted by this virus (Abdulamir \& Hafidh, 2020). More confounding is our inadequate understanding of the virus's high infectiveness, absence of active antivirals and vaccines, and the potential asymptomatic transmission have made managing COVID-19 very challenging. Therefore, knowledge of the viral structure and possible pathogenic mechanisms would provide essential insight into its management and much more, development of antivirus and vaccine. This review is one of many attempts towards providing a compact report on what is known so far about the virus, with respect to potential therapeutic targets.

\section{Structures and Functions of SARS-CoV-2 Proteins}

The genomic sequence of SARS-CoV-2 is nearly identical to the genomes of the human SARS-CoV virus. Coronavirus is a spherical shaped particle with an envelope and size ranging from $100-160 \mathrm{~nm}$ in diameter. They are positive-sense single-stranded RNA genome of $27-32 \mathrm{~kb}$ in size. Among RNA viruses, they represent the largest genome with $\mathrm{G}+\mathrm{C}$ content ranging from $32 \%$ to $43 \%$ (Cui, $\mathrm{Li}, \& \mathrm{Shi}, 2019$ ). The envelope involves of glycoprotein projections that are club-shaped. Hemagglutinin-esterase protein (HE) is also a constituent of a few of the corona viruses (de Haan, Kuo, Masters, Vennema, \& Rottier, 1998). The viral genome contains distinctive features, like the N-terminal fragment within the spike protein (Woo, Huang, Lau, \& Yuen, 2010). At the 5 '-terminal 2/3rd of the genome, the first Open Reading Frames (ORFa/b), encodes 16 non-structural proteins that are involved in genome transcription and replication. Two polypeptides, ppla and pplab, are produced by a frameshift contained in between ORF1a and ORF1b. Virally encoded chymotrypsin-like protease (3CLpro) or main protease (Mpro) and two papain-like proteases processes these two polypeptides into 16 non-structural proteins (NSP). The structural and accessory proteins are translated from the sgRNAs of CoVs (Boheemen et al., 2012; Czub, Weingartl, Czub, He, \& Cao, 2005; Mousavizadeh \& Ghasemi, 2020). The 3' terminus encodes structural proteins, including envelope glycoprotein spike (S), membrane (M), envelope (E), and nucleocapsid (N) in ORFs 10 and 11 positions. Other accessory genes are species-specific and dispensable for virus replication (Czub et al., 2005; Fan et al., 2020).

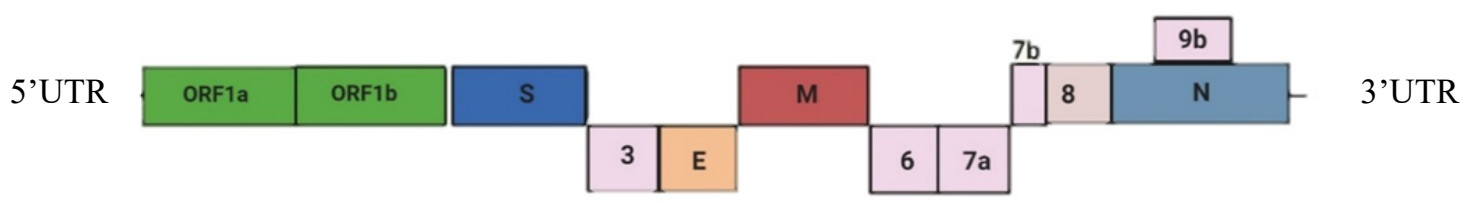

SARS-CoV-2 genome structure

Figure 1. SARS-CiV2 Genome Structure (created with BioRender.com) 
SARS-CoV-2 has four structural proteins. The Spike protein (S) is a transmembrane glycoprotein that forms homotrimers that protrude from the viral surface. The $\mathrm{S}$ protein is a class I fusion protein that helps in receptor attachment (P. K. C. Cheng et al., 2020). It mediates viral entry into the host cells (Corman, Muth, Niemeyer, \& Drosten, 2020). The approximate size of the $\mathrm{S}$ protein is $150 \mathrm{kDa}$ (Reid, de Waal, \& de Waal, 2012). Trimers present in the $\mathrm{S}$ protein forms a peculiar spike structure on the viral surface (Beniac, Andonov, Grudeski, \& Booth, 2006; Delmas \& Laude, 1990). The host protease cleaves the S protein into two different functional sub-unit S1 and S2 (P. K. C. Cheng et al., 2020). S1 is involved in receptor binding and S2 gives structural support in the form of stalk of S protein for a fusion of viral and cellular membrane (P. K. C. Cheng et al., 2020; Ge et al., 2013). In the S1 subunit, there are two different domains to enter the cell. They are named as SA and SB. SARS-CoV and SARSrelated coronavirus interact with angiotensin-converting enzyme 2 (ACE2) via domain SB to enter the target cells. It has been recently discovered that SARS-CoV-2 binds to the ACE2 receptor via SB domain similarly to SARS-CoV (Kirchdoerfer et al., 2018; W. Li et al., 2003a; Song, Gui, Wang, \& Xiang, 2018).

The membrane protein $(\mathrm{M})$, is a $25-30 \mathrm{kDa}$ glycosylated hydrophobic protein and it has three transmembrane domains consisting of an $\mathrm{N}$ - or O- glycosylated site at the $\mathrm{N}$ terminus, found in abundance in the virion (Armstrong, Niemann, Smeekenst, Rottiert, \& Warren, 1984; C. Chan et al., 2005). It is believed to play an important role in organizing particle assembly. It exists in the virion as a dimer and helps in maintaining the membrane curvature and binding to the nucleocapsid (Godet, Haridon, Vautherot, \& Laude, 2020).

The Envelope (E) protein is a transmembrane protein with a size of $8-12 \mathrm{kDa}$, found scarcely in the virion (Godet et al., 2020). E protein has ion channel activity and it is a protein with a C-terminal endo-domain and $\mathrm{N}$-terminal ectodomain. The important role of E protein is in viral assembly and release. It also plays a major role in the pathogenesis of SARS-CoV infection and possibly, in SARS-CoV-2 infection (Nieto-torres et al., 2014).

The Nucleocapsid (N) has a C-terminal domain and an N-terminal domain with each domain capable of binding RNA (Chang et al., 2006; Hurst, Koetzner, \& Masters, 2009). The N-protein has two substrates, TRSs, and genomic packaging signals. It is highly phosphorylated which increases its binding ability to viral RNA and gives a characteristic beads-on-a-string structure (Childes \& Stohlnan, 1979). The main role of N protein is to help package the encapsulated viral genome into the viral particles using the M protein and nsp3 to enhance binding to the replicase-transcriptase complex (RTC) (Hurst et al., 2009; Hurst, Koetzner, \& Masters, 2013; Sturman, Holmes, \& Behnke, 1980).

Some of the $\beta$-coronaviruses also contain hemagglutinin-esterase (HE). It is found on the surface of virion and binds to sialic acids present in glycoproteins. It facilitates viral entry into the host cells mediated by the $\mathrm{S}$ protein. It could also facilitate mucosa viral spread (Cornelissen et al., 1997; Klausegger et al., 1999).

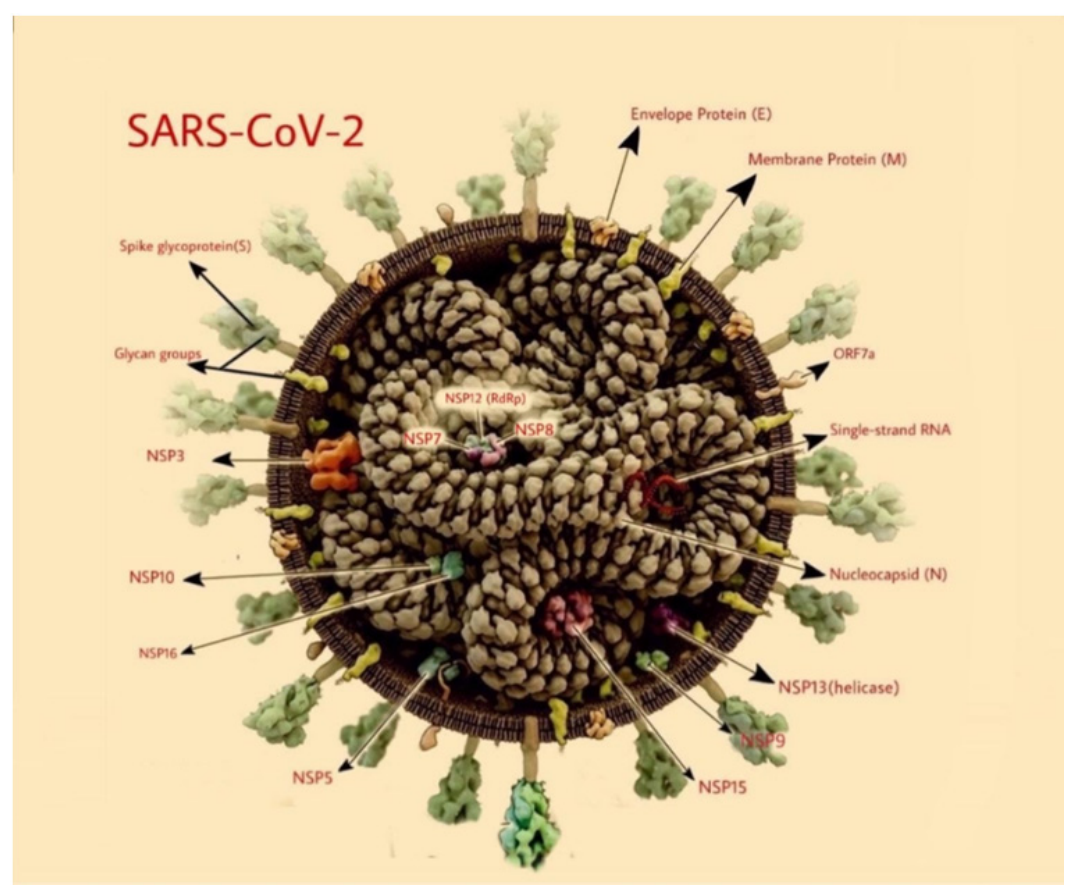

Figure 2. SARS-CoV-2 structures (modified) (46) 


\section{Rapid Spread of SARS-CoV-2; A Comparison of SARS-CoV and MERS-CoV-}

SARS-CoV-2 has become a global menace with rapid spread and increasing mortality across countries compared to the SARS-CoV. The difference in the structure of the $\mathrm{S}$ protein has been postulated to be responsible for this high virulence and mortality rate. Thus, it is imperative to study viral entry into host cells using the $\mathrm{S}$ protein in different coronaviruses (Reid et al., 2012).

The main mechanism of viral entry into the host cells is through $\mathrm{S}$ protein and its receptor. The receptor-binding domain (RBD) of S protein within the S1 domain lies in either N-terminus and C-terminus of S1 (P. K. C. Cheng et al., 2020; Kubo \& Yamada, 1994). Both SARS-CoV and SARS-CoV-2 use angiotensin-converting enzyme (ACE2) as their receptors. The RBD of the S1 domain uses 14 amino acid residues to bind to the ACE2 receptor. Among these 14 amino acids, 8 amino acids are present in SARS-CoV-2 (Coronavirus, 2020). After attachment to the host cells, the virus enters the cytosol of the host cells by using proteases such as cathepsin and TM-PRRS2. These 2 proteases cleave the S protein, followed by fusion of the host and viral cell membranes. The cleavage of S protein occurs in two different positions; the first cleavage separates the RBD and fusion domains while the second fusion exposes fusion peptides (Belouzard, Chu, \& Whittaker, 2009). The SARS-CoV and SARS-CoV-2 have the same furin-like S2' cleavage site at KR $\downarrow$ SF with P1 and P2 basic residues and P2' hydrophobic Phe downstream to the internal fusion protein. The S protein of SARS-CoV-2 has 12 extra nucleotides upstream to the single Arg $\downarrow$ as cleavage site (Braun \& Sauter, 2019; Convertases \& Izaguirre, 2019). The presence of this furin-like cleavage site in SARS-CoV-2 facilitates the $\mathrm{S}$ protein priming and seems to increase the efficiency of the spread of SARS-CoV-2 as compared to other betacoronaviruses (Coutard et al., 2020; Millet \& Whittaker, 2014).

On the basis of various structural and biochemical studies, another possibility of SARS-CoV-2 to infect humans widely than other coronaviruses like SARS-CoV and MERS-CoV is the RBD amino acids which are essential for binding to ACE2 receptor and determining the host. The coordinates of SARS-CoV are Y442, L472, N479, D480, T487, and Y4911, which correspond to L455, F486, Q493, S494, N501 and Y505 in SARS-CoV-2. Five of these six residues differ between SARS-CoV-2 and SARS-CoV (Andersen, Rambaut, Lipkin, Holmes, \& Garry, 2020). There is curiosity about the kinetics of this interaction which was demonstrated by plasma resonance. The ACE2 bound to 2019-nCoVs ectodomain is $\sim 15 \mathrm{nM}$ which is 10 to 20 folds higher than ACE2 binding to SARS-CoVS. The high affinity of SARS-CoV-2 to the ACE-2 receptor could be the reason for the apparent ease of SARS-CoV-2 spread from human to human. Knowledge about the atomic-level structure of the $2019-\mathrm{nCoV}$ spike will be important information for additional protein-engineering efforts that could improve antigenicity and protein expression for vaccine development (Wrapp et al., 2020).

\section{Pathogenesis:}

There is still a wide knowledge gap in our understanding of the pathogenesis of COVID-19. However, it has been found that there are similarities between the pathogenesis of SARS-CoV and MERS-CoV. It is presumed that the attack of SARS-CoV-2 undergoes three stages: viral replication, hyper-reactivity of the immune system, and pulmonary destruction (Hoffmann et al., 2020).

\subsection{SARS-Cov-2 Life Cycle}

1) SARS-CoV-2 enters target cells either by an endosomal pathway (Du et al., 2009) or by plasma membrane fusion (Hoffmann et al., 2020).

2) In both pathways, Glycoprotein $\mathrm{S}((\mathrm{S} 1, \mathrm{~S} 2)$, present in the virus envelope, interacts with the cellular receptor ACE2 on human cells (F. Wu et al., 2020).

3) Once virions move toward endosomes, the spike protein would be activated by either cathepsin $\mathrm{L}$ or the cellular serine protease TMPRSS2 near to the ACE2 receptor, which begins fusion of the plasma membrane with the viral membrane (Belouzard et al., 2009; Kuba, Imai, Ohto-Nakanishi, \& Penninger, 2010; H. Wang et al., 2008).

4) Upon entrance into the cell, the envelope is desquamated, allowing genomic RNA to be present in the cytoplasm.

5) The genomic RNA produces the ORF1a and ORF1b RNAs and then translates into ppla and pplab proteins, respectively (Adnan, Khan, Kazmi, Bashir, \& Siddique, 2020).

6) Following that, both ppla and ppalb proteins undergo cleavage via proteases such as the Papain-like protease $\left(\mathrm{Pl}^{\mathrm{pro})}\right.$ and $3 \mathrm{C}$-like protease (3CL ${ }^{\mathrm{pro})}$ to produce 16 nonstructural proteins (NSP) altogether.

7) Some of these NSPs develop a replication/transcription complex (RNA-dependent RNA polymerase, RdRp), which utilizes the genomic RNA (+) as a template. 
8) The genomic RNA (+) develops into the genome of the new virus molecule.

9) Later, subgenomic RNAs created via the transcription are converted into structural proteins (S: spike protein, E: envelope protein, M: membrane protein, and N: nucleocapsid protein) which create a viral particle.

10) These structural proteins (S,E,M) go through the endoplasmic reticulum; the N-protein is then merged with the genomic RNA (+) to develop a nucleoprotein complex.

11) They merge into the full virus particle in the endoplasmic reticulum-Golgi apparatus compartment and are discharged to the extracellular region via the Golgi apparatus and the vesicle via exocytosis (Du et al., 2009; Jiang, Hillyer, \& Du, 2020).

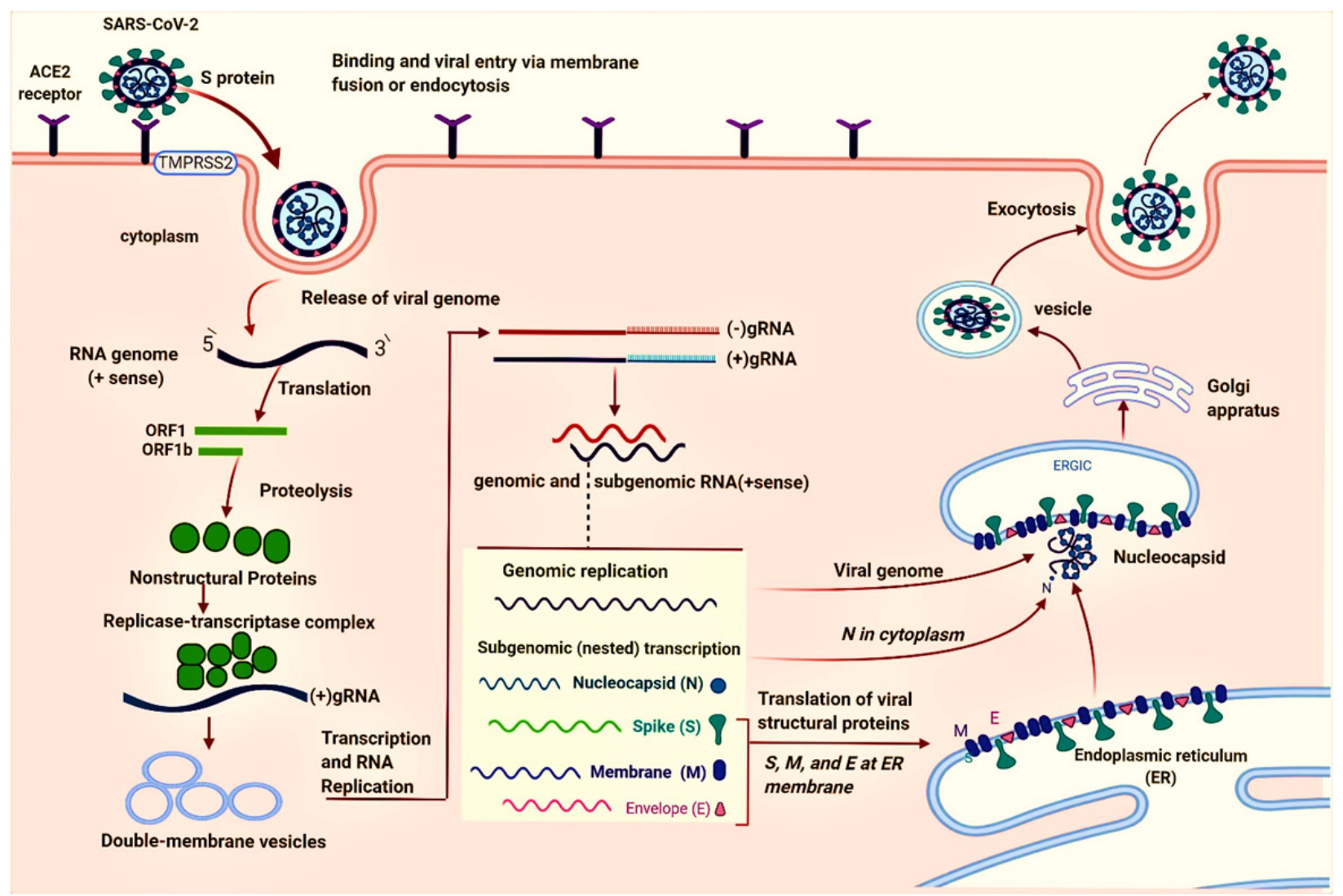

Figure 3. SARS-CoV-2 life cycle (created with BioRender.com)

\subsection{Clinical Outcomes}

There are two prominent features that have been observed in severe and critical COVID-19 patients: the progressive rise of inflammation, and an uncommon trend of hypercoagulation (W. Cao \& Li, 2020). Clinical studies report additional characteristics, such as high venous thromboembolism rates, elevated D-dimer levels, high fibrinogen levels, low anti-thrombin levels, and pulmonary congestion with microvascular thrombosis. High rates of central line thrombosis and vascular occlusive events, such as Ischemic limbs, strokes were observed in patients with COVID-19 (Kuba et al., 2005; J. Wang et al., 2020).

The initial report of clinical outcomes from a severe COVID-19 case revealed pulmonary bilateral diffuse alveolar destruction with cellular fibro myxoid exudates (Z. Xu et al., 2020). It showed clear apparent desquamation of pneumocytes and hyaline membrane formation in the right lung which implies acute respiratory distress syndrome. In the left lung tissue, it exhibited pulmonary edema with hyaline membrane formation which implied early-phase acute respiratory distress syndrome (ARDS). Amphophilic granular cytoplasm, multinucleated syncytial cells with atypical enlarged pneumocytes characterized via large nuclei, and prominent nucleoli were found in the intra-alveolar spaces, implying viral cytopathic-like changes. These pulmonary pathological results are exceptionally similar to those detected in both SARS and MERS (Ding et al., 2003; Ng et al., 2016). Additionally, moderate microvascular steatosis and mild lobular and portal activity were seen in liver biopsy specimens, 
suggesting the direct cytotoxicity due to either SARS-CoV-2 infection or anoxia or drug use. Interstitial mononuclear inflammatories infiltrate were observed in the heart tissue, implying that SARS-CoV-2 might not directly impair the heart (Z. Xu et al., 2020).

Another report showed great amounts of mucus secretion in both lungs of several death cases with COVID-19, which differed from SARS and MERS (Jin et al., 2020). Hemoglobin and neutrophil counts were decreased in patients with novel COVID-19. Whereas the index values of serum ferritin, C-reactive protein, erythrocyte sedimentation rate albumin, and lactate dehydrogenase of many patients were meaningfully increased, indicating that SARS-COV-2 could directly attack hemoglobin and prevent the heme anabolic pathway, leading to a wide range of infection and disease (wenzhong \& hualan, 2020). Cardiac injury is a common condition among hospitalized patients with COVID-19 in Wuhan, China, and it is associated with a higher risk of in-hospital mortality. In 416 patients of whom 57 died, the cardiac injury was a common finding (19.7\%). In the patients who died, $10.6 \%$ had coronary artery disease (CAD), $4.1 \%$ had HF, and $5.3 \%$ had cerebrovascular disease ("ESC Guidance for the Diagnosis and Management of CV Disease during the COVID-19 Pandemic," n.d.). The table below shows the Association of Cardiac Injury with Mortality in Hospitalized Patients With COVID-19 in Wuhan, China.

Table 1. Baseline Features and Laboratory Outcomes of 416 Patients With COVID-19 (Shi et al., 2020)

\begin{tabular}{|c|c|c|c|c|}
\hline \multirow{3}{*}{ Characteristic } & \multicolumn{4}{|c|}{ Patients, No. (\%) } \\
\hline & \multicolumn{3}{|c|}{ Cardiac injury } & \multirow[b]{2}{*}{ P-value } \\
\hline & All $(n=416)$ & With $(\mathrm{n}=82)$ & Without $(\mathrm{n}=334)$ & \\
\hline Age, median (range), y & $64(21-95)$ & $74(34-95)$ & $60(21-90)$ & $<.001$ \\
\hline Female & $211(50.7)$ & $38(46.3)$ & $173(51.8)$ & .39 \\
\hline \multicolumn{5}{|l|}{ Chronic medical disease } \\
\hline Coronary heart disease & $44(10.6)$ & $24(29.3)$ & $20(6.0)$ & $<.001$ \\
\hline Cerebrovascular disease & $22(5.3)$ & $13(15.9)$ & $9(2.7)$ & $<.001$ \\
\hline Chronic heart failure & $17(4.1)$ & $12(14.6)$ & $5(1.5)$ & $<.001$ \\
\hline Chronic renal failure & $14(3.4)$ & $5(6.1)$ & $9(2.7)$ & .16 \\
\hline Chronic obstructive pulmonary disease & $12(2.9)$ & $6(7.3)$ & $6(1.8)$ & .02 \\
\hline \multicolumn{5}{|c|}{ Laboratory outcomes at admission, median (IQR) } \\
\hline Leukocytes $/ \mu \mathrm{L}$ & $5800(4300-8300)$ & $9400(6900-13800)$ & $5500(4200-7400)$ & $<.001$ \\
\hline Lymphocytes/ $\mu \mathrm{L}$ & $900(600-1300)$ & $600(400-900)$ & $1000(800-1400)$ & $<.001$ \\
\hline Hemoglobin, g/dL & $12.4(11.1-13.4)$ & $12.5(10.8-13.2)$ & $12.4(11.2-13.5)$ & .34 \\
\hline C-reactive protein, $\mathrm{mg} / \mathrm{dL}$ & $4.5(1.4-8.5)$ & $10.2(6.4-17.0)$ & $3.7(1.0-7.3)$ & $<.001$ \\
\hline Creatinine kinase-myocardial band, $\mathrm{ng} / \mathrm{mL}$ & $1.0(0.7-2.0)$ & $3.2(1.8-6.2)$ & $0.9(0.6-1.3)$ & $<.001$ \\
\hline
\end{tabular}

\subsection{Physiopathology}

The clinical progression of SARS-CoV-2 disease occurs in three stages: the viremia stage, the acute stage (pneumonia phase), and the severity or recovery stage (W. Cao \& Li, 2020). Current data indicate that the clinical signs of patients with COVID-19 include cough, fever, nonproductive, dyspnea, myalgia, fatigue, decreased leukocyte counts, and the radiographic sign of pneumonia (Huang et al., 2020b).

Acute Respiratory Distress Syndrome (ARDS) is a life-threatening lung disorder that inhibits enough oxygen from reaching the lungs and into the circulation which is responsible for death in most acute lung injury cases as well as respiratory disorders (Thompson, Chambers, \& Liu, 2017). Clinical studies demonstrate exuberant inflammatory responses during SARS-CoV-2 infection giving rise to uncontrolled pulmonary infection that would end up causing a fatality. Several possible mechanisms have been suggested about the pathogenetic pathways of SARS-CoV-2. Virus-generated ACE2 downregulation and shedding, rapid viral replication and cellular damage, and antibody-dependent enhancement (ADE) are examples of possible pathways (see figure 4) (Fu, Cheng, \& Wu, 2020). Like SARS-CoV, SARS-CoV-2 hijacks ACE2 receptor for infection, proposing the possibility of targeting 
the same type of cells (Gu et al., 2005). Acute lung injury also has been suggested to be attributed to the loss of pulmonary ACE2 function (Imai, Kuba, \& Penninger, 2008) since ACE2 downregulation and shedding could give rise to dysfunction of the renin-angiotensin system (RAS), and thus augment inflammation and cause vascular permeability.

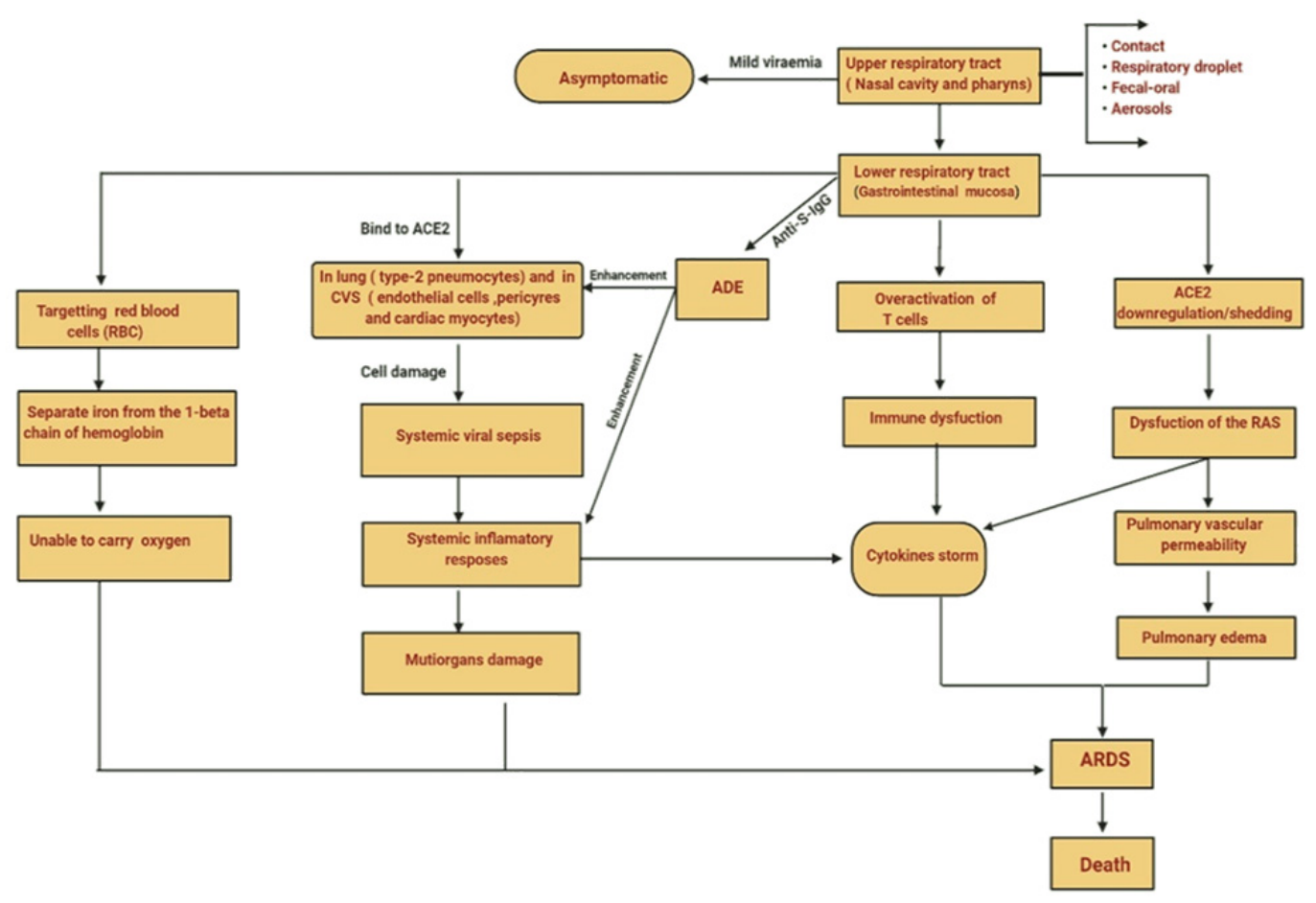

Figure 4. Pathogenesis of SARS-CoV-2 infection (Created with BioRender.com)

In experimental models of SARS-CoV infection, Spike protein engagement decreases ACE2 expression and activates the RAS (Kuba et al., 2005). Activation of RAS will stimulate platelet adhesion and aggregation and increases the risk of pulmonary embolism, hypertension, and fibrosis (CHUNG et al., 2007; Marshall, 2005). Many factors may play an important role in coagulation disorder in COVID-19 patients. The continued inflammatory status in severe and critical COVID-19 patients' functions as a crucial trigger for the coagulation cascade. Specific cytokines such as IL-6 might trigger the coagulation system and suppress the fibrinolytic system (W. Cao \& Li, 2020).

Studies suggest that SARS-CoV-2 attacks hemoglobin in the red blood cells through a series of cellular actions resulting in the incapability of the red blood cells to transport oxygen. Consequently, the lungs are stressed out and become inflamed (resulting in ARDS). The capability of the SARS-CoV-2 to disrupt the iron-porphyrin bond was assessed via comparison of the conserved domains of heme oxidase (the host enzyme that oxidizes heme and separates iron ion) and viral proteins. It was observed that orflab, ORF10, and ORF3a proteins can separate iron from the 1-beta chain of hemoglobin and ORF8 and surface glycoprotein may perhaps attach to porphyrin (Wenzhong \& Hualan, 2020).

Another potential underlying mechanism of antibody-dependent enhancement (ADE) has been proposed lately (Fu et al., 2020). ADE is a well-established virology phenomenon. It has been verified in various viral infections (Takada \& Kawaoka, 2003). ADE can stimulate viral cellular uptake of the infectious virus-antibody complexes after they interact with $\mathrm{Fc}$ receptors $(\mathrm{FcR}), \mathrm{Fc} \gamma \mathrm{R}$, or other receptors, leading to enhanced infection of target cells (Takada \& Kawaoka, 2003). The interaction of the virus-anti-S protein-neutralizing antibodies (anti-S-IgG) complex with FcyR could facilitate the inflammatory responses and persistent viral replication in the lungs of patients (Fu et al., 2020). This phenomenon was observed in a few patients who generate neutralizing antibodies early, facing continued inflammation, ARDS, and unexpected mortality, whereas most patients survive the inflammatory reactions and clear out the virus (Fu et al., 2020). What is more, COVID-19 could be contributing to cardiovascular diseases (CVD). It has been observed in patients several days after the initiation of fever, 
suggesting a possible upregulation of ACE2 in the heart and coronary vessels, or respiratory failure and hypoxia, or triggering the immune system which may also cause CVS damage. To illustrate, respiratory tract infection by SARS-CoV-2 is expressed via the progression of systemic inflammation and immune cell over-activation leading to cytokine storm including li6, li22, and CXCL10. As a result, the stimulated T cell and macrophage could infiltrate infected myocardium, leading to the development of fulminant myocarditis and severe cardiac damage. It has been reported that infection of endothelial cells or pericytes could lead to microvascular and macrovascular dysfunction. Also, immune over-reactivity could potentially destabilize atherosclerotic plaques, leading to the development of acute coronary syndromes ("ESC Guidance for the Diagnosis and Management of CV Disease during the COVID-19 Pandemic," n.d.).

\subsection{Immunopathology}

Not only the cardiorespiratory system is liable to be infected by a virus, but also the immune system could be impacted which can influence its function as the illness progresses ("Laboratory abnormalities in patients with COVID-2019 infection in: Clinical Chemistry and Laboratory Medicine (CCLM) - Ahead of print," n.d.; Zhou et al., 2020). The viral entrance, as well as cell infection, activates the host's immune response, and the inflammatory cascade is started via antigen-presenting cells (APC). The process begins when APC presents the foreign antigen to CD4 +-T-helper (Th1) cells, and release interleukin-12 to activate the Th1 cell. The Th1 cells which activate CD8 +-T-killer (Tk) cells to target any cell comprising the foreign antigen. The activated Th1 cells could stimulate B-cells to yield antigen-specific antibodies (Rabi, Al Zoubi, Al-Nasser, Kasasbeh, \& Salameh, 2020). The antigen presentation of SARS-CoV primarily relies upon major histocompatibility complex (MHC) I molecules (Zhou et al., 2020); however, MHC II could also take part in its presentation. After antigen presentation, the body's humoral and cellular immunity via virus-specific $\mathrm{T}$ and $\mathrm{B}$ cells will be activated. The antibody profile against the SARS-CoV virus has a typical pattern of $\operatorname{IgG}$ and $\operatorname{IgM}$ output like common acute viral infections. The SARS-specific IgM antibodies usually vanish in week 12, whereas the $\operatorname{IgG}$ antibody continues for a long time, which implies the possible protective function of IgG antibody (G. Li, Chen, \& Xu, 2003), and the SARS-specific IgG antibodies mainly are S-specific and N-specific antibodies (J. T. Wu, Leung, \& Leung, 2020).

SARS-CoV-2 mostly acts on lymphocytes, mainly T lymphocytes, and stimulates a cytokine storm in the body and therefore produces a series of immune responses (see Figure 4). In a cohort of 452 patients with COVID-19 enrolled from January 10 to February 12, 2020. 286 patients were detected with severe COVID-19 infection. The laboratory outcomes showed an increase in white blood cell and neutrophil lymphopenia ratio (NLR), whereas, the percentages of eosinophils, monocytes, and basophils were lower. The amounts of B cells, T cells, and NK cells were drastically reduced in severe cases. T cells were displayed to be most impacted via SARS-CoV-2, and more hampered in severe cases (Tian et al., n.d.). High concentrations of proinflammatory CD4 T cells and cytotoxic granules CD8 T cells were also determined, suggesting antiviral immune responses and overactivation of $T$ cells ( $Z$. $\mathrm{Xu}$ et al., 2020). Additionally, several reports have stated that lymphopenia is a common characteristic of COVID-19 (Huang et al., 2020b; Zhu et al., 2020), indicative of a crucial factor responsible for severity and death.

Elevated plasma levels of pro-inflammatory cytokines in conjunction with chemokines such as IFN- $\gamma$, IL-1 $\beta$, IP-10, and MCP-1) were shown in COVID-19 patients, while in severe cases, the concentrations of TNF- $\alpha$, G-CSF, MCP-1, IP-10, IL-8, IL-10, and MIP-1A were elevated (Huang et al., 2020b; Tian et al., n.d.). The elevation of IL-6 expression in serum as well as IL-2 receptor has also been reported in severe cases which could pave the way for detecting the severity of COVID-19 (L et al., 2020; Tian et al., n.d.). It has been reported that the upregulation of pro-inflammatory cytokines in serum was linked to inflammation and severe pulmonary damage in COVID-19 patients (Huang et al., 2020b). Surprisingly, high levels of both Th1 and Th2 cytokines were reported in SARS-CoV-2 infection compared with SARS and MERS where only Th1 cytokines were upregulated (Huang et al., 2020b; Wong et al., 2004). Earlier studies have observed that genetic susceptibility, as well as inflammatory cytokines, were closely linked to the occurrence of ARDS. Greater than 40 candidate genes involving ACE2, vascular endothelial growth factor (VEGF), interleukin 10 (IL-10), tumor necrosis factor (TNF), among others have been associated with the development or outcome of ARDS (Meyer \& Christie, 2013). Increased levels of plasma IL-6 and IL-8 were also demonstrated to be related to adverse outcomes of ARDS (Thompson et al., 2017). These biomarkers could pave the way for a further molecular explanation of the severe ARDS and a potential therapy for ARDS following SARS -CoV-2 infection.

In addition, SARS-CoV-2 binds to Toll-like Receptors (TLR) to activate the release of pro-IL1b and consequently producing mature IL-1b, which facilitates pulmonary inflammation, fever, and fibrosis (Conti et al., 2020). Hence, suppression of IL-1b and other members of pro-inflammatory IL-family by IL37 and IL-38 may prove highly beneficial in COVID-19 patients to reduce pulmonary inflammation and might be considered as a relevant 
therapeutic agent (Conti et al., 2020).

\section{Genetic Variety and Development of SARS-CoV-2}

The genomic characteristics of SARS-CoV-2 have been under scrutiny in order to define the pathogenesis and disease course, develop diagnostic, therapeutic, and vaccine formulations (Laamarti et al., 2020). It has been shown that the SARS-COV-2 genome has a much lower mutation rate and genetic variety compared to SARS during the 2002-2003 outbreak (Jia et al., 2020). An earlier study conducted with population genetic analysis of 103 genomes of SARS-CoV-2, found that SARS-CoV-2 viruses evolved into two different mutants (L and S types) and both were well defined by just two SNPs that show nearly complete linkage across SARS-CoV-2 strains. The study shows L type $(\sim 70 \%)$ was more abundant than $\mathrm{S}$ type $(\sim 30 \%)$. The $\mathrm{L}$ type is more aggressive than $\mathrm{S}$ type, which is the ancestral version of SARS-CoV-2. During the early stage of the outbreak in Wuhan, the L-mutant was prevalent but after January, this decreased. It is believed that human intervention may have placed more severe selective pressure on the L type, which might be more aggressive and spread more quickly. On the other hand, the $\mathrm{S}$ type, which is evolutionarily older and less aggressive, might have increased in relative frequency due to relatively weaker selective pressure (Almeida \& Tyrrell, 1967; Ciotti \& Minieri, 2020; Kapikian et al., 1969; Song et al., 2018).

Studies show that ORFs and ACE2 genes play a crucial role in the pathogenesis of the disease. A genomic study by Khailany et al demonstrated that $8782 \mathrm{C}>\mathrm{T}$ in ORF1ab gene, 28144T $>\mathrm{C}$ in ORF8 gene, and 29095C $>\mathrm{T}$ in the $\mathrm{N}$ gene were the commonest among 116 mutations after analyzing 95 SARS-CoV-2 complete genomes (Khailany, Safdar, \& Ozaslan, 2020). Three earlier reported mutations (M5865V, S5932F and R203K) were identified in ORF1 ab and N respectively (Pachetti et al., 2020a).

Another genomic analysis conducted on over 3,000 strains of SARS-CoV-2 revealed over 700 mutations, out of which roughly two-thirds led to an alteration in the amino acid sequence of the protein whereas, the rest were in the intergenic regions. 39 non-synonymous mutations were detected with a prevalence of more than $0.06 \%$ or at least 20 of the analyzed genomes. The mutations were found in 6 genes especially replicase polyprotein (ORF1ab), spike protein, membrane glycoprotein, nucleocapsid phosphoprotein, ORF3, and ORF8. Importantly, the substantial number of non-synonymous mutations has mostly existed in the ORF1ab gene, which encodes 16 NSPs (Khailany et al., 2020; Laamarti et al., 2020). Among these proteins, NSP12, NSP3, and NSP2 have a great numeral of mutations 61,117 , and 61 , respectively. The gene itself shows more than half of the recurrent mutations, with 22 mutations in helicase proteinase, the RNA-dependent RNA polymerase, transmembrane domains, and endo-RNAase exonuclease. 10 mutations were observed as hotspots at a frequency greater than 0.10 , among all frequent mutations in this research. The D614G mutation in the gene encoding the spike protein was the most represented occurring in $44 \%$ of genomes, whereas the L84S at ORF8 was the second, in $32 \%$ of genomes. Four mutation hotspots were observed in ORF 1 which appeared in $11 \%$ to $17 \%$ of the genomes in each case (Laamarti et al., 2020).

In a compilation of mutant genomes from 59 countries, 26 had singleton mutations while many others had multiple mutations. Every continent had 3 of these mutations i.e. the G251V (in ORF3a), L84S (in ORF8), and S5932F (in ORF1ab), excluding Africa and Australia. Unlike other continents, the Asian strains lacked 3 mutations- F924F, L4715L in ORF1ab, and D614G in spike and an intergenic variant. It has been observed that common mutations were in Algerian and European strains, as in European and Dutch genomes, which displayed ten frequent mutations. Australian and African genomes took part in mutations at four positions, and two positions via Asian genomes. The most substantial variability was detected in Australia, New Zealand, and the US (Laamarti et al., 2020; Pachetti et al., 2020b). It is believed that these genomic mutations may be a key factor in the severity and spread of SARS-CoV-2.

\section{Potential Therapeutic Targets}

In the fight against COVID-19, several approaches have been considered. Currently, treatment is largely supportive and preventive. Current approaches involve symptomatic treatment measures, hydroxychloroquine (200 mg 12 hourly), chloroquine (500 mg 12 hourly), lopinavir/ritonavir (400/100 mg 12 hourly), alpha-interferon (e.g. 5million units by aerosol inhalation twice per day) among other evidence-based measures adopted worldwide globally (Cascella, Rajnik, Cuomo, Dulebohn, \& Di Napoli, 2020).

As with other pathogens of interest in humans, possible treatment strategies have been jeered towards exploiting various stages in the pathophysiology of the virus. The frequency of mutations in the proteins involved in the repair of viral replication errors poses a great challenge in the development of effective treatment and more importantly, a vaccine, with several genomic sequences published across different countries (Angeletti et al., 2020). Due to the 
severity of the pandemic, an initial therapeutic strategy has been to explore existing drugs for possible action against the virus, known as drug repurposing. This strategy is quite beneficial as the safety profiles of those drugs are known and thus, should facilitate their prompt availability for usage.

An early glimmer of hope was seen with Chloroquine, an age-long anti-malarial agent belonging to the 4-aminoquinoline family, which alters the $\mathrm{pH}$ of intracellular components by inhibiting acidification (Ohkuma \& Poole, 1978; Slater, 1993). In vitro and in vivo studies reveal a significant reduction in viral replication when Chloroquine was tested on members of the coronavirus family (Colson, Rolain, Lagier, Brouqui, \& Raoult, 2020; Keyaerts et al., 2009; Keyaerts, Vijgen, Maes, Neyts, \& Ranst, 2004; Kono et al., 2008). This is brought about by the modulation of terminal glycosylation of the ACE 2 receptor, which the coronavirus family, especially the beta coronaviruses, uses for cell entry (Ksiazek et al., 2003; W. Li et al., 2003b; Vincent et al., 2005). Hydroxychloroquine, another member of the 4-aminoquinoline family, used for malaria prophylaxis and in certain autoimmune conditions, was also explored for its antiviral properties due to it pharmacokinetic and -dynamic similarity to Chloroquine ("Hydroxychloroquine Sulfate Monograph for Professionals - Drugs.com," n.d.; Juurlink, 2020). More so, Hydroxychloroquine has a better safety profile compared to Chloroquine and thus would be a preferred candidate amongst members of the 4-aminoquinoline family. Still following through with the drug repurposing strategy, the macrolide, Azithromycin (azithromycin dihydrate; N-Methyl-11-aza-10-deoxo-10-dihydroerythromycin A), having shown antiviral activity against Zika virus (Bosseboeuf et al., 2018; C. Li et al., 2019) was added to the growing list of potential agents against SARS-CoV-2. Azithromycin was shown to attack the zika virus at a very late stage in its lifecycle and more importantly, improves host immune response by upregulating interferon I and III levels (C. Li et al., 2019). Thus, researchers proposed a combination of Chloroquine/Hydroxychloroquine with Azithromycin would yield a synergistic effect and enhance more virus clearance. Several clinical trials were initiated across different countries to validate these bench results clinically and results have been at best, ambiguous with many reporting no significant benefit (Andreani et al., 2020; Colson et al., 2020; Gautret et al., 2020; Geleris et al., 2020; "NIH Begins Clinical Trial of Hydroxychloroquine and Azithromycin to Treat COVID-19," n.d.; "Study finds no hydroxychloroquine effect on death, severe COVID-19 | CIDRAP," n.d.; Tripathy, Dassarma, Roy, Chabalala, \& Matsabisa, 2020). Despite off-label uses across many centers in the management of COVID-19, there have been safety concerns with usage, especially with the combination ("Chloroquine for COVID-19: Cutting Through the Hype I The Scientist Magazine $($,” n.d.; Juurlink, 2020; Mehra, Desai, Ruschitzka, \& Patel, 2020). This made the WHO halt its solidarity trial on hydroxychloroquine ("WHO Stops Study Of Experimental Drug Hydroxychloroquine: Coronavirus Live Updates: NPR," n.d.).

Initial attempts at a cure exploited the similarity of the SARS-CoV-2 to the Human Immunodeficiency Virus (HIV). The SARS-CoV was suggested to share a similar analogous membrane fusion mechanism with HIV, as its spike protein S2 shares the same two $\alpha$ helices with gp41 of HIV (Kliger \& Levanon, 2003; X. W. Zhang \& Yap, 2004). Investigations on this have not been significantly progressive, as the SARS-CoV-2 seems to have other means of entry into cells (Báez-Santos, St. John, \& Mesecar, 2015; De Clercq, 2006; Liu et al., 2004; Mirza \& Froeyen, 2020). Consequent to this shared property, the protease inhibitor, Lopinavir/Ritonavir was recruited for possible activity against SARS-CoV-2. Lopinavir inhibits the HIV-1 protease, needed for the formation of structural proteins and enzymes by the virus, thus leading to the production of immature, non-infectious viral offsprings (Chandwani \& Shuter, 2008). The combination of Lopinavir/Ritonavir is expedient as the Ritonavir helps increase the half-life of Lopinavir and thus makes for a longer duration of action, which can help prevent a re-infection or second wave of infection (Flexner, 1998). In vitro studies reveal a good level of activity against the SARS-CoV virus, with significant inhibition of viral replication. Despite an apparent favorable clinical outcome obtained in early trials of the drug (K. S. Chan et al., 2003; Chu et al., 2004) subsequent trials of the drug, however, didn't produce significant improvements in outcome, but it is still advocated as part of the management protocol for COVID-19 ("A Trial of Lopinavir-Ritonavir in Covid-19," 2020; B. Cao et al., 2020).

The ACE2, a component of the RAS, functions as a counterregulatory and protective agent against the well-known Angiotensin-Converting Enzyme (ACE). It breaks down Angiotensin II into Angiotensin (1-7), thus diminishing its effects. ACE2 has been identified as the primary initial entry point for the SARS-CoV-2 which provides a viable potential therapeutic target (Kuhn, Li, Choe, \& Farzan, 2004; W. Li et al., 2003a; Moore et al., 2004). Studies exploiting this gateway have not yielded much success. This we propose could be partly due to the downregulation of the enzyme by the virus (Glowacka et al., 2010) and the absence of an existing effective ACE2 inhibitor (Ferrario et al., 2005; Hamming et al., 2008; Rice, Thomas, Grant, Turner, \& Hooper, 2004). A randomized trial investigating the protective ability of ACE inhibitors revealed a $40 \%$ decrease in the rate of hospitalization among elderly patients infected with COVID-19 (Khera, 2020). Other trials conducted did not report any significant 
benefit or harm associated with its use (Khera, 2020; Mackey et al., 2020; Mancia, Rea, Ludergnani, Apolone, \& Corrao, 2020).

In vitro studies using the RNA polymerase inhibitor, Remdesivir (GS5734) showed potent activity against multiple RNA viruses such as Ebola and is currently undergoing trials as a possible prophylactic and therapeutic agent against SARS-CoV-2 (Gordon, Tchesnokov, Feng, Porter, \& Götte, 2020). Remdesivir causes premature chain termination by incorporating itself into nascent viral RNA chains (Agostini et al., 2018; Sheahan et al., 2017). In vitro and in vivo studies have demonstrated its ability to reduce viral load and potentially inhibit human infection (Sheahan et al., 2017; M. Wang et al., 2020). Preliminary results of the first stage of the Adaptive Covid-19 Treatment Trial (ACTT-1), in which treatment with remdesivir was compared with placebo revealed a significant reduction in the recovery time of the treated group against the control group (Finberg et al., 2020). This has led to continued further trials with hopes of favorable outcomes.

A humanized IgG1 monoclonal antibody directed at the IL-6 receptor, Tocilizumab, is currently under investigation (Luo et al., 2020). Pneumonia caused by SARS-CoV-2 is associated with a cytokine storm in which IL-6 levels are found to be predominantly high (C. Zhang, Wu, Li, Zhao, \& Wang, 2020). Early results showed an improvement in the pulmonary conditions of infected patients (X. Xu et al., 2020). As this does not affect the virus in any way, it may not offer a direct therapeutic respite against SARS-CoV-2 but can surely help mitigate the effects of the virus, reducing morbidity and mortality.

While the race for a putative treatment is still on, we believe from these available pieces of evidence and studies, that although the hopes of an effective monotherapy may be slim, combination therapies seem to hold better hopes in the fight against SARS-CoV-2, as also posited by Biegel at al (Finberg et al., 2020). With the ongoing WHO SOLIDARITY trial, we expect more clarity in the hunt for a potential therapy for COVID-19.

\section{Conclusion}

The incessant viral mutations and paucity of in-depth trials continue to militate against the progress made in the fight against COVID-19. However, the continuous emergence of findings of the SARS-CoV-2 raises a lot of potential for therapeutic targets and vaccine development. Shared similarities and drug repurposing remain popular strategies gaining increased exploration as the world awaits a respite in the ongoing fight against COVID-19.

\section{Competing Interests Statement}

The authors declare that there are no competing or potential conflicts of interest.

\section{References}

A Trial of Lopinavir-Ritonavir in Covid-19. (2020). https://doi.org/10.1056/NEJMC2008043

Abdulamir, A. S., \& Hafidh, R. R. (2020). The possible immunological pathways for the variable immunopathogenesis of COVID - 19 infections among healthy adults, elderly and children. Electronic Journal of General Medicine, 17(4), 1-4. https://doi.org/10.29333/ejgm/7850

Adnan, M., Khan, S., Kazmi, A., Bashir, N., \& Siddique, R. (2020). COVID-19 infection : Origin, transmission, and characteristics of human coronaviruses. Journal of Advanced Research, 24, 91-98. https://doi.org/10.1016/j.jare.2020.03.005

Agostini, M. L., Andres, E. L., Sims, A. C., Graham, R. L., Sheahan, T. P., Lu, X., ... Denison, M. R. (2018). Coronavirus Susceptibility to the Antiviral Remdesivir (GS-5734) Is Mediated by the Viral Polymerase and the Proofreading Exoribonuclease. MBio, 9(2). https://doi.org/10.1128/mBio.00221-18

Almeida, J. D., \& Tyrrell, D. A. (1967). The morphology of three previously uncharacterized human respiratory viruses that grow in organ culture. The Journal of General Virology, 1(2), 175-178. https://doi.org/10.1099/0022-1317-1-2-175

Andersen, K. G., Rambaut, A., Lipkin, W. I., Holmes, E. C., \& Garry, R. F. (2020). The proximal origin of SARS-CoV-2. Nature Medicine, 2-4. https://doi.org/10.1038/s41591-020-0820-9

Andreani, J., Le Bideau, M., Duflot, I., Jardot, P., Rolland, C., Boxberger, M., ... Raoult, D. (2020). In vitro testing of combined hydroxychloroquine and azithromycin on SARS-CoV-2 shows synergistic effect. Microbial Pathogenesis, 145(April), 0-3. https://doi.org/10.1016/j.micpath.2020.104228

Angeletti, S., Benvenuto, D., Bianchi, M., Giovanetti, M., Pascarella, S., \& Ciccozzi, M. (2020). COVID-2019: The role of the nsp2 and nsp3 in its pathogenesis. Journal of Medical Virology, 92(6), 584-588. https://doi.org/10.1002/jmv.25719 
Armstrong, J., Niemann, H., Smeekenst, S., Rottiert, P., \& Warren, G. (1984). Sequence and topology of a model intracellular membrane protein, El glycoprotein, from a coronavirus. 38-39.

Backer, J. A., Klinkenberg, D., \& Wallinga, J. (2020). Incubation period of 2019 novel coronavirus (2019- nCoV) infections among travellers from Wuhan, China, 2028 January 2020. Eurosurveillance, 25(5), 1-6. https://doi.org/10.2807/1560-7917.ES.2020.25.5.2000062

Báez-Santos, Y. M., St. John, S. E., \& Mesecar, A. D. (2015, March 1). The SARS-coronavirus papain-like protease: Structure, function and inhibition by designed antiviral compounds. Antiviral Research, 115, 21-38. https://doi.org/10.1016/j.antiviral.2014.12.015

Beigel, J. H., Tomashek, K. M., Dodd, L. E., Mehta, A. K., Zingman, B. S., Kalil, A. C., ... \& de Castilla, D. L. (2020). Remdesivir for the treatment of Covid-19-preliminary report. The New England journal of medicine. https://doi.org/10.1056/NEJMoa2007764

Belouzard, S., Chu, V. C., \& Whittaker, G. R. (2009). Activation of the SARS coronavirus spike protein via sequential proteolytic cleavage at two distinct sites. Proceedings of the National Academy of Sciences, 106(14), 5871-5876.

Beniac, D. R., Andonov, A., Grudeski, E., \& Booth, T. F. (2006). Architecture of the SARS coronavirus prefusion spike. Nature Structural and Molecular Biology, 13(8), 751-752. https://doi.org/10.1038/nsmb1123

Boheemen, S. Van, Graaf, M. De, Lauber, C., Bestebroer, T. M., Raj, V. S., Zaki, A. M., ... Fouchier, R. A. M. (2012). Genomic Characterization of a Newly Discovered Coronavirus. MBio, 3(6), 1-9. https://doi.org/10.1128/mBio.00473-12.Editor

Bosseboeuf, E., Aubry, M., Nhan, T., de Pina, J. J., Rolain, J. M., Raoult, D., \& Musso, D. (2018). Azithromycin Inhibits the Replication of Zika Virus. Journal of Antivirals \& Antiretrovirals, 10(1). https://doi.org/10.4172/1948-5964.1000173

Braun, E., \& Sauter, D. (2019). Furin-mediated protein processing in infectious diseases and cancer Furin, 8, 1-19. https://doi.org/10.1002/cti2.1073

Cao, B., Wang, Y., Wen, D., Liu, W., Wang, J., Fan, G., ... Wang, C. (2020). A trial of lopinavir-ritonavir in adults hospitalized with severe covid-19. New England Journal of Medicine, 382(19), 1787-1799. https://doi.org/10.1056/NEJMoa2001282

Cao, W., \& Li, T. (2020). COVID-19: towards understanding of pathogenesis. Cell Research, 30(5), 367-369. https://doi.org/10.1038/s41422-020-0327-4

Cascella, M., Rajnik, M., Cuomo, A., Dulebohn, S. C., \& Di Napoli, R. (2020). Features, Evaluation and Treatment Coronavirus (COVID-19). In Stat Pearls. Retrieved from http://www.ncbi.nlm.nih.gov/pubmed/32150360

Chan, K. S., Lai, S. T., Chu, C. M., Tsui, E., Tam, C. Y., Wong, M. M. L., ... Yuen, K. Y. (2003). Treatment of severe acute respiratory syndrome with lopinavir/ritonavir: A multicentre retrospective matched cohort study. Hong Kong Medical Journal, 9(6), 399-406.

Chandwani, A., \& Shuter, J. (2008). Lopinavir/ritonavir in the treatment of HIV-1 infection: A review. Therapeutics and Clinical Risk Management, 4, 1023-1033. https://doi.org/10.2147/tcrm.s3285

Chang, C., Sue, S., Yu, T., Hsieh, C., Tsai, C., Chiang, Y., ... Huang, T. (2006). Modular organization of SARS coronavirus nucleocapsid protein (pp. 59-72). https://doi.org/10.1007/s11373-005-9035-9

Cheng, P. K. C., Wong, D. A., Tong, L. K. L., Ip, S., Lo, A. C. T., Lau, C., ... Lim, W. W. L. (2020). Since January 2020 Elsevier has created a COVID-19 resource centre with free information in English and Mandarin on the novel coronavirus COVID-19. The COVID-19 resource centre is hosted on Elsevier Connect, the company's public news and information (January).

Cheng, Y., Luo, R., Wang, K., Zhang, M., Wang, Z., Dong, L., ... Xu, G. (2020). Kidney disease is associated with in-hospital death of patients with COVID-19. Kidney International, 97(5), 829-838. https://doi.org/10.1016/j.kint.2020.03.005

Chloroquine for COVID-19: Cutting Through the Hype | The Scientist Magazine®. (n.d.). Retrieved May 28, 2020, from

https://www.the-scientist.com/news-opinion/is-hype-over-chloroquine-as-a-potential-covid-19-therapy-justi fied--67301 
Chu, C. M., Cheng, V. C. C., Hung, I. F. N., Wong, M. M. L., Chan, K. H., Chan, K. S., .. Yuen, K. Y. (2004). Role of lopinavir/ritonavir in the treatment of SARS: Initial virological and clinical findings. Thorax, 59(3), 252-256. https://doi.org/10.1136/thorax.2003.012658

Chung, T., Connor, D., Joseph, J., Emmett, L., Mansberg, R., Peters, M., ... Kritharides, L. (2007). Platelet activation in acute pulmonary embolism. Journal of Thrombosis and Haemostasis, 5(5), 918-924. https://doi.org/10.1111/j.1538-7836.2007.02461.x

Ciotti, M., \& Minieri, M. (2020). COVID-19 Outbreak: An Overview. https://doi.org/10.1159/000507423

Colson, P., Rolain, J. M., Lagier, J. C., Brouqui, P., \& Raoult, D. (2020). Chloroquine and hydroxychloroquine as available weapons to fight COVID-19. International Journal of Antimicrobial Agents, 55(4), 105932. https://doi.org/10.1016/j.ijantimicag.2020.105932

Conti, P., Ronconi, G., Caraffa, A., Gallenga, C., Ross, R., Frydas, I., \& Kritas, S. (2020). Induction of pro-inflammatory cytokines (IL-1 and IL-6) and lung inflammation by Coronavirus-19 (COVI-19 or SARS-CoV-2): anti-inflammatory strategies. Journal of Biological Regulators and Homeostatic Agents, 34(2). https://doi.org/10.23812/CONTI-E

Convertases, O. P., \& Izaguirre, G. (2019). The proteolytic regulation of virus cell entry by furin and other proprotein convertases. Viruses, 11(9), 837.

Corman, V. M., Muth, D., Niemeyer, D., \& Drosten, C. (2020). Free information in English and Mandarin on the novel coronavirus COVID- Hosts and Sources of Endemic Human Coronaviruses. (January).

Cornelissen, L. A., Wierda, C. M., Van Der Meer, F. J., Herrewegh, A. A., Horzinek, M. C., Egberink, H. F., \& De Groot, R. J. (1997). Hemagglutinin-esterase, a novel structural protein of torovirus. Journal of virology, 71(7), 5277-5286.

Coronavirus Disease (COVID-19) Situation Reports. (n.d.). Retrieved June 16, 2020, from https://www.who.int/emergencies/diseases/novel-coronavirus-2019/situation-reports

Coronavirus, S. (2020). Crossm Receptor Recognition by the Novel Coronavirus from Wuhan: an Analysis Based on Decade-Long Structural Studies of. (January), 1-9.

Coutard, B., Valle, C., Lamballerie, X. De, Canard, B., Seidah, N. G., \& Decroly, E. (2020). The spike glycoprotein of the new coronavirus 2019-nCoV contains a furin- like cleavage site absent in $\mathrm{CoV}$ of the same clade. Antiviral Research, 176(February), 104742. https://doi.org/10.1016/j.antiviral.2020.104742

Cui, J., Li, F., \& Shi, Z. L. (2019). Origin and evolution of pathogenic coronaviruses. Nature Reviews Microbiology, 17(3), 181-192. https://doi.org/10.1038/s41579-018-0118-9

Czub, M., Weingartl, H., Czub, S., He, R., \& Cao, J. (2005). Evaluation of modified vaccinia virus Ankara based

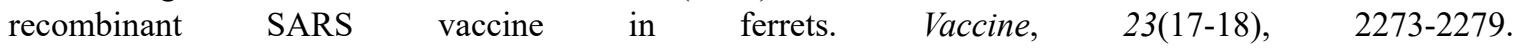
https://doi.org/10.1016/j.vaccine.2005.01.033

De Clercq, E. (2006, April). Potential antivirals and antiviral strategies against SARS coronavirus infections. Expert Review of Anti-Infective Therapy, 4, 291-302. https://doi.org/10.1586/14787210.4.2.291

de Haan, C. A. M., Kuo, L., Masters, P. S., Vennema, H., \& Rottier, P. J. M. (1998). Coronavirus Particle Assembly: Primary Structure Requirements of the Membrane Protein. Journal of Virology, 72(8), 6838-6850. https://doi.org/10.1128/jvi.72.8.6838-6850.1998

Delmas, B., \& Laude, H. (1990). Assembly of coronavirus spike protein into trimers and its role in epitope expression. Journal of Virology, 64(11), 5367-5375. https://doi.org/10.1128/jvi.64.11.5367-5375.1990

Ding, Y., Wang, H., Shen, H., Li, Z., Geng, J., Han, H., ... Yao, K. (2003). The clinical pathology of severe acute respiratory syndrome (SARS): A report from China. Journal of Pathology, 200(3), 282-289. https://doi.org/10.1002/path.1440

Du, L., He, Y., Zhou, Y., Liu, S., Zheng, B. J., \& Jiang, S. (2009). The spike protein of SARS-CoV - A target for vaccine and therapeutic development. Nature Reviews Microbiology, 7(3), 226-236. https://doi.org/10.1038/nrmicro2090

ESC Guidance for the Diagnosis and Management of CV Disease during the COVID-19 Pandemic. (n.d.). Retrieved June 7, 2020, from https://www.escardio.org/Education/COVID-19-and-Cardiology/ESC-COVID-19-Guidance

Fan, C., Li, K., Ding, Y., Lu, W. L., \& Wang, J. (2020). ACE2 Expression in Kidney and Testis May Cause Kidney 
and Testis Damage After 2019-nCoV Infection. MedRxiv, 2020.02.12.20022418. https://doi.org/10.1101/2020.02.12.20022418

Fehr, A. R., \& Perlman, S. (2015). Coronaviruses: An overview of their replication and pathogenesis. In Coronaviruses: Methods and Protocols (Vol. 1282, pp. 1-23). https://doi.org/10.1007/978-1-4939-2438-7_1

Ferrario, C. M., Jessup, J., Chappell, M. C., Averill, D. B., Brosnihan, K. B., Tallant, E. A., ... Gallagher, P. E. (2005). Effect of angiotensin-converting enzyme inhibition and angiotensin II receptor blockers on cardiac $\begin{array}{lllll}\text { angiotensin-converting } & \text { enzyme } & 2 . & \text { Circulation, } & 111(20),\end{array}$ https://doi.org/10.1161/CIRCULATIONAHA.104.510461

Flexner, C. (1998, April 30). HIV-protease inhibitors (A. J. J. Wood, Ed.). New England Journal of Medicine, 338 , 1281-1292. https://doi.org/10.1056/NEJM199804303381808

$\mathrm{Fu}$, Y., Cheng, Y., \& Wu, Y. (2020). Understanding SARS-CoV-2-Mediated Inflammatory Responses: From Mechanisms to Potential Therapeutic Tools. Virologica Sinica, p. 1. https://doi.org/10.1007/s12250-020-00207-4

Gautret, P., Lagier, J. C., Parola, P., Hoang, V. T., Meddeb, L., Sevestre, J., .. Raoult, D. (2020). Clinical and microbiological effect of a combination of hydroxychloroquine and azithromycin in 80 COVID-19 patients with at least a six-day follow up: A pilot observational study. Travel Medicine and Infectious Disease. https://doi.org/10.1016/j.tmaid.2020.101663

Ge, X. Y., Li, J. L., Yang, X. Lou, Chmura, A. A., Zhu, G., Epstein, J. H., ... Shi, Z. L. (2013). Isolation and characterization of a bat SARS-like coronavirus that uses the ACE2 receptor. Nature, 503(7477), 535-538. https://doi.org/10.1038/nature12711

Geleris, J., Sun, Y., Platt, J., Zucker, J., Baldwin, M., Hripcsak, G., ... Schluger, N. W. (2020). Observational Study of Hydroxychloroquine in Hospitalized Patients with Covid-19. New England Journal of Medicine. https://doi.org/10.1056/nejmoa2012410

Glowacka, I., Bertram, S., Herzog, P., Pfefferle, S., Steffen, I., Muench, M. O., ... Pöhlmann, S. (2010). Differential Downregulation of ACE2 by the Spike Proteins of Severe Acute Respiratory Syndrome Coronavirus and Human Coronavirus NL63. Journal of Virology, 84(2), 1198-1205. https://doi.org/10.1128/jvi.01248-09

Godet, M., Haridon, R. L., Vautherot, J., \& Laude, H. (2020). Since January 2020 Elsevier has created a COVID-19 resource centre with free information in English and Mandarin on the novel coronavirus COVID19. The COVID-19 resource centre is hosted on Elsevier Connect, the company's public news and information. (January).

Gordon, C. J., Tchesnokov, E. P., Feng, J. Y., Porter, D. P., \& Götte, M. (2020). The antiviral compound remdesivir potently inhibits RNAdependent RNA polymerase from Middle East respiratory syndrome coronavirus. Journal of Biological Chemistry, 295(15), 4773-4779. https://doi.org/10.1074/jbc.AC120.013056

Gu, J., Gong, E., Zhang, B., Zheng, J., Gao, Z., Zhong, Y., ... Leong, A. S. Y. (2005). Multiple organ infection and the pathogenesis of SARS. Journal of Experimental Medicine, 202(3), 415-424. https://doi.org/10.1084/jem.20050828

Guan, G. W., Gao, L., Wang, J. W., Wen, X. J., Mao, T. H., Peng, S. W., .. Lu, F. M. (2020). Exploring the mechanism of liver enzyme abnormalities in patients with novel coronavirus-infected pneumonia. Zhonghua Gan Zang Bing Za Zhi = Zhonghua Ganzangbing Zazhi = Chinese Journal of Hepatology, 28(2), $100-106$. https://doi.org/10.3760/cma.j.issn.1007-3418.2020.02.002

Hamming, I., Van Goor, H., Turner, A. J., Rushworth, C. A., Michaud, A. A., Corvol, P., \& Navis, G. (2008). Differential regulation of renal angiotensin-converting enzyme (ACE) and ACE2 during ACE inhibition and dietary sodium restriction in healthy rats. Experimental Physiology, 93(5), 631-638. https://doi.org/10.1113/expphysiol.2007.041855

Hoffmann, M., Kleine-Weber, H., Schroeder, S., Krüger, N., Herrler, T., Erichsen, S., ... Pöhlmann, S. (2020). SARS-CoV-2 Cell Entry Depends on ACE2 and TMPRSS2 and Is Blocked by a Clinically Proven Protease Inhibitor. Cell, 181(2), 271-280.e8. https://doi.org/10.1016/j.cell.2020.02.052

Huang, C., Wang, Y., Li, X., Ren, L., Zhao, J., Hu, Y., ... Cao, B. (2020a). Clinical features of patients infected with 2019 novel coronavirus in Wuhan, China. The Lancet, 395(10223), 497-506. https://doi.org/10.1016/S0140-6736(20)30183-5 
Huang, C., Wang, Y., Li, X., Ren, L., Zhao, J., Hu, Y., ... Cao, B. (2020b). Clinical features of patients infected with 2019 novel coronavirus in Wuhan, China. The Lancet, 395(10223), 497-506. https://doi.org/10.1016/S0140-6736(20)30183-5

Hurst, K. R., Koetzner, C. A., \& Masters, P. S. (2009). Identification of in vivo-interacting domains of the murine coronavirus nucleocapsid protein. Journal of virology, 83(14), 7221-7234. https://doi.org/10.1128/JVI.00440-09

Hurst, K. R., Koetzner, C. A., \& Masters, P. S. (2013). Characterization of a critical interaction between the coronavirus nucleocapsid protein and nonstructural protein 3 of the viral replicase-transcriptase complex. Journal of virology, 87(16), 9159-9172. https://doi.org/10.1128/JVI.01275-13

Hydroxychloroquine Sulfate Monograph for Professionals - Drugs.com. (n.d.). Retrieved May 26, 2020, from https://www.drugs.com/monograph/hydroxychloroquine-sulfate.html

Imai, Y., Kuba, K., \& Penninger, J. M. (2008). The discovery of angiotensin-converting enzyme 2 and its role in acute lung injury in mice. Experimental Physiology, 93(5), 543-548. https://doi.org/10.1113/expphysiol.2007.040048

Jia, Y., Shen, G., Zhang, Y., Huang, K.-S., Ho, H.-Y., Hor, W.-S., ... Wang, W.-L. (2020). Analysis of the mutation dynamics of SARS-CoV-2 reveals the spread history and emergence of RBD mutant with lower ACE2 binding affinity. BioRxiv, 2020.04.09.034942. https://doi.org/10.1101/2020.04.09.034942

Jiang, S., Hillyer, C., \& Du, L. (2020, May 1). Neutralizing Antibodies against SARS-CoV-2 and Other Human Coronaviruses. Trends in Immunology, Vol. 41, pp. 355-359. https://doi.org/10.1016/j.it.2020.03.007

Jin, Y., Yang, H., Ji, W., Wu, W., Chen, S., Zhang, W., \& Duan, G. (2020). Virology, epidemiology, pathogenesis, and control of covid-19. Viruses, 12. https://doi.org/10.3390/v12040372

Juurlink, D. N. (2020). Safety considerations with chloroquine, hydroxychloroquine and azithromycin in the management of SARS-CoV-2 infection. CMAJ: Canadian Medical Association Journal $=$ Journal de l'Association Medicale Canadienne, 192(17), E450. https://doi.org/10.1503/cmaj.200528

Kapikian, A. Z., James, H. D., Kelly, S. J., Dees, J. H., Turner, H. C., McIntosh, K., ... Chanock, R. M. (1969). Isolation from man of "avian infectious bronchitis virus-like" viruses (coronaviruses) similar to $229 \mathrm{e}$ virus, with some epidemiological observations. Journal of Infectious Diseases, 119(3), 282-290. https://doi.org/10.1093/infdis/119.3.282

Keyaerts, E., Li, S., Vijgen, L., Rysman, E., Verbeeck, J., Van Ranst, M., \& Maes, P. (2009). Antiviral activity of chloroquine against human coronavirus OC43 infection in newborn mice. Antimicrobial Agents and Chemotherapy, 53(8), 3416-3421. https://doi.org/10.1128/AAC.01509-08

Keyaerts, E., Vijgen, L., Maes, P., Neyts, J., \& Ranst, M. Van. (2004). In vitro inhibition of severe acute respiratory syndrome coronavirus by chloroquine. Biochemical and Biophysical Research Communications, 323(1), 264-268. https://doi.org/10.1016/j.bbrc.2004.08.085

Khailany, R. A., Safdar, M., \& Ozaslan, M. (2020). Genomic characterization of a novel SARS-CoV-2. Gene Reports, 19, 100682. https://doi.org/10.1016/j.genrep.2020.100682

Khera, R. (2020). Association of Angiotensin-Converting Enzyme Inhibitors and Angiotensin Receptor Blockers with the Risk of Hospitalization and Death in Hypertensive Patients with Coronavirus Disease-19.

Kirchdoerfer, R. N., Wang, N., Pallesen, J., Wrapp, D., Turner, H. L., Cottrell, C. A., ... Ward, A. B. (2018). Stabilized coronavirus spikes are resistant to conformational changes induced by receptor recognition or proteolysis. Scientific Reports, (October), 1-11. https://doi.org/10.1038/s41598-018-34171-7

Klausegger, A., Strobl, B., Regl, G., Kaser, A., Luytjes, W., \& Vlasak, R. (1999). Identification of a coronavirus hemagglutinin-esterase with a substrate specificity different from those of influenza $\mathrm{C}$ virus and bovine coronavirus. Journal of virology, 73(5), 3737-3743.

Kliger, Y., \& Levanon, E. Y. (2003). Cloaked similarity between HIV-1 and SARS-CoV suggests an anti-SARS strategy. BMC Microbiology, 3, 1-7. https://doi.org/10.1186/1471-2180-3-20

Kono, M., Tatsumi, K., Imai, A. M., Saito, K., Kuriyama, T., \& Shirasawa, H. (2008). Inhibition of human coronavirus 229E infection in human epithelial lung cells (L132) by chloroquine: Involvement of p38 MAPK and ERK. Antiviral Research, 77(2), 150-152. https://doi.org/10.1016/j.antiviral.2007.10.011

Ksiazek, T. G., Erdman, D., Goldsmith, C. S., Zaki, S. R., Peret, T., Emery, S., ... Anderson, L. J. (2003). A novel 
coronavirus associated with severe acute respiratory syndrome. New England Journal of Medicine, 348(20), 1953-1966. https://doi.org/10.1056/NEJMoa030781

Kuba, K., Imai, Y., Ohto-Nakanishi, T., \& Penninger, J. M. (2010). Trilogy of ACE2: A peptidase in the renin-angiotensin system, a SARS receptor, and a partner for amino acid transporters. Pharmacology and Therapeutics, 128(1), 119-128. https://doi.org/10.1016/j.pharmthera.2010.06.003

Kuba, K., Imai, Y., Rao, S., Gao, H., Guo, F., Guan, B., ... Penninger, J. M. (2005). A crucial role of angiotensin converting enzyme 2 (ACE2) in SARS coronavirus-induced lung injury. Nature Medicine, 11(8), 875-879. https://doi.org/10.1038/nm1267

Kubo, H., Yamada, Y. K., \& Taguchi, F. (1994). Localization of neutralizing epitopes and the receptor-binding site within the amino-terminal 330 amino acids of the murine coronavirus spike protein. Journal of Virology, 68(9), 5403-5410.

Kuhn, J. H., Li, W., Choe, H., \& Farzan, M. (2004). Angiotensin-converting enzyme 2: a functional receptor for SARS coronavirus. Cellular and Molecular Life Sciences: CMLS, 61(21), 2738-2743. https://doi.org/10.1007/s00018-004-4242-5

Kutter, J. S., Spronken, M. I., Fraaij, P. L., Fouchier, R. A., \& Herfst, S. (2018). Transmission routes of respiratory

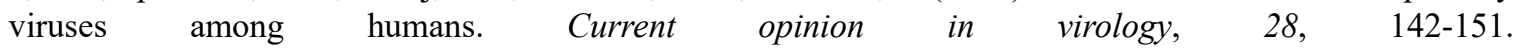
https://doi.org/10.1016/j.coviro.2018.01.001

L, C., HG, L., W, L., J, L., K, L., J, S., ... S, W. (2020). [Analysis of Clinical Features of 29 Patients With 2019 Novel Coronavirus Pneumonia]. Zhonghua Jie He He Hu Xi Za Zhi=Zhonghua Jiehe He Huxi Zazhi= Chinese Journal of Tuberculosis and Respiratory Diseases, 43(0). https://doi.org/10.3760/CMA.J.ISSN.1001-0939.2020.0005

Laamarti, M., Alouane, T., Kartti, S., Chemao-Elfihri, M. W., Hakmi, M., Essabbar, A., ... Ibrahimi, A. (2020). Large scale genomic analysis of 3067 SARS-CoV-2 genomes reveals a clonal geo-distribution and a rich genetic variations of hotspots mutations. BioRxiv, 2020.05.03.074567. https://doi.org/10.1101/2020.05.03.074567

Laboratory abnormalities in patients with COVID-2019 infection in: Clinical Chemistry and Laboratory Medicine (CCLM) - Ahead of print. (n.d.). Retrieved June 7, 2020, from https://www.degruyter.com/view/journals/cclm/ahead-of-print/article-10.1515-cclm-2020-0198/article-10.1 515-cclm-2020-0198.xml?language $=$ en

Li, C., Zu, S., Deng, Y. Q., Li, D., Parvatiyar, K., Quanquin, N., ... Cheng, G. (2019). Azithromycin protects against Zika virus infection by upregulating virus-induced type I and III interferon responses. Antimicrobial Agents and Chemotherapy, 63(12). https://doi.org/10.1128/AAC.00394-19

Li, G., Chen, X., \& Xu, A. (2003). Profile of Specific Antibodies to the SARS-Associated Coronavirus. New England Journal of Medicine, 349(5), 508-509. https://doi.org/10.1056/NEJM200307313490520

Li, W., Moore, M. J., Vasllieva, N., Sui, J., Wong, S. K., Berne, M. A., ... Farzan, M. (2003a). Angiotensin-converting enzyme 2 is a functional receptor for the SARS coronavirus. Nature, 426(6965), 450-454. https://doi.org/10.1038/nature02145

Li, W., Moore, M. J., Vasllieva, N., Sui, J., Wong, S. K., Berne, M. A., .. Farzan, M. (2003b). Angiotensin-converting enzyme 2 is a functional receptor for the SARS coronavirus. Nature, 426(6965), 450-454. https://doi.org/10.1038/nature02145

Liu, S., Xiao, G., Chen, Y., He, Y., Niu, J., Escalante, C. R., ... Jiang, S. (2004). Interaction between heptad repeat 1 and 2 regions in spike protein of SARS-associated coronavirus: Implications for virus fusogenic mechanism and identification of fusion inhibitors. Lancet, 363(9413), 938-947. https://doi.org/10.1016/S0140-6736(04)15788-7

Luo, P., Liu, Y., Qiu, L., Liu, X., Liu, D., \& Li, J. (2020). Tocilizumab treatment in COVID-19: A single center experience. Journal of Medical Virology, (March), 1-5. https://doi.org/10.1002/jmv.25801

Mackey, K., King, V. J., Gurley, S., Kiefer, M., Liederbauer, E., Vela, K., ... Kansagara, D. (2020). Risks and Impact of Angiotensin-Converting Enzyme Inhibitors or Angiotensin-Receptor Blockers on SARS-CoV-2 Infection in Adults. Annals of Internal Medicine, 1-10. https://doi.org/10.7326/M20-1515

Mancia, G., Rea, F., Ludergnani, M., Apolone, G., \& Corrao, G. (2020). Renin-Angiotensin-Aldosterone System Blockers and the Risk of Covid-19. The New England Journal of Medicine, 1-10. 
https://doi.org/10.1056/NEJMoa2006923

Marshall, R. (2005). The Pulmonary Renin-Angiotensin System. Current Pharmaceutical Design, 9(9), 715-722. https://doi.org/10.2174/1381612033455431

Mehra, M. R., Desai, S. S., Ruschitzka, F., \& Patel, A. N. (2020). Hydroxychloroquine or chloroquine with or without a macrolide for treatment of COVID-19: a multinational registry analysis. Lancet (London, England), 6736(20), 1-10. https://doi.org/10.1016/S0140-6736(20)31180-6

Meyer, N. J., \& Christie, J. D. (2013). Genetic heterogeneity and risk of acute respiratory distress syndrome. Seminars in Respiratory and Critical Care Medicine, 34(4), 459-474. https://doi.org/10.1055/s-0033-1351121

Millet, J. K., \& Whittaker, G. R. (2014). Host cell entry of Middle East respiratory syndrome coronavirus after two-step, furin-mediated activation of the spike protein. Proceedings of the National Academy of Sciences, 111(42), 15214-15219. https://doi.org/10.1073/pnas.1407087111

Mirza, M. U., \& Froeyen, M. (2020). Structural elucidation of SARS-CoV-2 vital proteins: Computational methods reveal potential drug candidates against main protease, Nsp12 polymerase and Nsp13 helicase. Journal of Pharmaceutical Analysis. https://doi.org/10.1016/j.jpha.2020.04.008

Moore, M. J., Dorfman, T., Li, W., Wong, S. K., Li, Y., Kuhn, J. H., ... Choe, H. (2004). Retroviruses Pseudotyped with the Severe Acute Respiratory Syndrome Coronavirus Spike Protein Efficiently Infect Cells Expressing Angiotensin-Converting Enzyme 2. Journal of Virology, 78(19), 10628-10635. https://doi.org/10.1128/jvi.78.19.10628-10635.2004

Mousavizadeh, L., \& Ghasemi, S. (2020). ScienceDirect Genotype and phenotype of COVID-19: Their roles in pathogenesis. Journal of Microbiology, Immunology and Infection, (xxxx), 0-4. https://doi.org/10.1016/j.jmii.2020.03.022

Nal, B., Chan, C., Kien, F., Siu, L., Tse, J., Chu, K., ... \& van der Werf, S. (2005). Differential maturation and subcellular localization of severe acute respiratory syndrome coronavirus surface proteins $\mathrm{S}, \mathrm{M}$ and $\mathrm{E}$. Journal of general virology, 86(5), 1423-1434. https://doi.org/10.1099/vir.0.80671-0

Ng, D. L., Al Hosani, F., Keating, M. K., Gerber, S. I., Jones, T. L., Metcalfe, M. G., ... Zaki, S. R. (2016). Clinicopathologic, immunohistochemical, and ultrastructural findings of a fatal case of middle east respiratory syndrome coronavirus infection in the United Arab Emirates, April 2014. American Journal of Pathology, 186(3), 652-658. https://doi.org/10.1016/j.ajpath.2015.10.024

Nieto-Torres, J. L., DeDiego, M. L., Verdiá-Báguena, C., Jimenez-Guardeño, J. M., Regla-Nava, J. A., Fernandez-Delgado, R., ... \& Enjuanes, L. (2014). Severe acute respiratory syndrome coronavirus envelope protein ion channel activity promotes virus fitness and pathogenesis. PLoS Pathog, 10(5), e1004077. https://doi.org/10.1371/journal.ppat.1004077

NIH Begins Clinical Trial of Hydroxychloroquine and Azithromycin to Treat COVID-19. (n.d.). Retrieved May 28, 2020, from https://health.ucsd.edu/news/releases/Pages/2020-05-15-nih-begins-clinical-trial-ofhydroxychloroquine-azithromycin-to-treat-covid-19.aspx

Ohkuma, S., \& Poole, B. (1978). Fluorescence probe measurement of the intralysosomal pH in living cells and the perturbation of $\mathrm{pH}$ by various agents. Proceedings of the National Academy of Sciences of the United States of America, 75(7), 3327-3331. https://doi.org/10.1073/pnas.75.7.3327

Pachetti, M., Marini, B., Benedetti, F., Giudici, F., Mauro, E., Storici, P., ... Ippodrino, R. (2020a). Emerging SARS-CoV-2 mutation hot spots include a novel RNA-dependent-RNA polymerase variant. Journal of Translational Medicine, 18(1), 1-9. https://doi.org/10.1186/s12967-020-02344-6

Pachetti, M., Marini, B., Benedetti, F., Giudici, F., Mauro, E., Storici, P., ... Ippodrino, R. (2020b). Emerging SARS-CoV-2 mutation hot spots include a novel RNA-dependent-RNA polymerase variant. Journal of Translational Medicine, 18(1), 179. https://doi.org/10.1186/s12967-020-02344-6

Peters, A., Vetter, P., Guitart, C., Lotfinejad, N., \& Pittet, D. (2020). Understanding the emerging coronavirus: what it means for health security and infection prevention. Journal of Hospital Infection, 104(4), 440-448. https://doi.org/10.1016/j.jhin.2020.02.023

Rabi, F. A., Al Zoubi, M. S., Al-Nasser, A. D., Kasasbeh, G. A., \& Salameh, D. M. (2020, March 1). Sars-cov-2 and coronavirus disease 2019: What we know so far. Pathogens, Vol. 9. https://doi.org/10.3390/pathogens9030231 
Reid, K., de Waal, M., \& de Waal, M. J. (2012). A Comparative Overview*. Exploring the Law of SuccessionStudies National, Historical and Comparative, (2002), 1-26. https://doi.org/10.3366/edinburgh/9780748632909.003.0011

Rice, G. I., Thomas, D. A., Grant, P. J., Turner, A. J., \& Hooper, N. M. (2004). Evaluation of angiotensin-converting enzyme (ACE), its homologue ACE2 and neprilysin in angiotensin peptide metabolism. Biochemical Journal, 383(1), 45-51. https://doi.org/10.1042/BJ20040634

Sheahan, T. P., Sims, A. C., Graham, R. L., Menachery, V. D., Gralinski, L. E., Case, J. B., ... Baric, R. S. (2017). Broad-spectrum antiviral GS-5734 inhibits both epidemic and zoonotic coronaviruses. Science Translational Medicine, 9(396). https://doi.org/10.1126/scitranslmed.aal3653

Shi, S., Qin, M., Shen, B., Cai, Y., Liu, T., Yang, F., ... Huang, C. (2020). Association of Cardiac Injury with Mortality in Hospitalized Patients with COVID-19 in Wuhan, China. JAMA Cardiology. https://doi.org/10.1001/jamacardio.2020.0950

Slater, A. F. G. (1993). Chloroquine: Mechanism of drug action and resistance in plasmodium falciparum. Pharmacology and Therapeutics, 57(2-3), 203-235. https://doi.org/10.1016/0163-7258(93)90056-J

Song, W., Gui, M., Wang, X., \& Xiang, Y. (2018). Cryo-EM structure of the SARS coronavirus spike glycoprotein in complex with its host cell receptor ACE2. 1-19.

Stohlman, S. A., \& Lai, M. M. (1979). Phosphoproteins of murine hepatitis viruses. Journal of virology, 32(2), $672-675$.

Study finds no hydroxychloroquine effect on death, severe COVID-19 | CIDRAP. (n.d.). Retrieved May 28, 2020, from

https://www.cidrap.umn.edu/news-perspective/2020/05/study-finds-no-hydroxychloroquine-effect-death-se vere-covid-19

Sturman, L. S., Holmes, K. V., \& Behnke, J. (1980). Isolation of coronavirus envelope glycoproteins and interaction with the viral nucleocapsid. Journal of virology, 33(1), 449-462.

Takada, A., \& Kawaoka, Y. (2003, November). Antibody-dependent enhancement of viral infection: Molecular mechanisms and in vivo implications. Reviews in Medical Virology, 13, 387-398. https://doi.org/10.1002/rmv.405

Thompson, B. T., Chambers, R. C., \& Liu, K. D. (2017, August 10). Acute respiratory distress syndrome. New England Journal of Medicine, 377, 562-572. https://doi.org/10.1056/NEJMra1608077

Tian, D.-S., Qin, C., Zhou, L., Hu, Z., Zhang, S., Yang, S., ... Tian, D.-S. (n.d.). Dysregulation of Immunity in COVID-19 • cid 2020:XX (XXXXXX) • 1 Clinical Infectious Diseases Clinical Infectious Diseases ${ }^{\circledR}$ 2020;XX(XX):1-7 Dysregulation of Immune Response in Patients With Coronavirus 2019 (COVID-19) in Wuhan, China. https://doi.org/10.1093/cid/ciaa248

Tripathy, S., Dassarma, B., Roy, S., Chabalala, H., \& Matsabisa, M. G. (2020). A review on possible modes of actions of Chloroquine/ Hydroxychloroquine: Repurposing against SAR-COV-2 (COVID 19) pandemic. International Journal of Antimicrobial Agents, 106028. https://doi.org/10.1016/j.jjantimicag.2020.106028

Van Doremalen, N., Bushmaker, T., Morris, D. H., Holbrook, M. G., Gamble, A., Williamson, B. N., ... Munster, V. J. (2020, April 16). Aerosol and surface stability of SARS-CoV-2 as compared with SARS-CoV-1. New England Journal of Medicine, 382, 1564-1567. https://doi.org/10.1056/NEJMc2004973

Vincent, M. J., Bergeron, E., Benjannet, S., Erickson, B. R., Rollin, P. E., Ksiazek, T. G., ... Nichol, S. T. (2005). Chloroquine is a potent inhibitor of SARS coronavirus infection and spread. Virology Journal, 2(1), 69. https://doi.org/10.1186/1743-422X-2-69

Wang, D., Hu, B., Hu, C., Zhu, F., Liu, X., Zhang, J., ... Peng, Z. (2020). Clinical Characteristics of 138 Hospitalized Patients with 2019 Novel Coronavirus-Infected Pneumonia in Wuhan, China. JAMA - Journal of the American Medical Association, 323(11), 1061-1069. https://doi.org/10.1001/jama.2020.1585

Wang, H., Yang, P., Liu, K., Guo, F., Zhang, Y., Zhang, G., \& Jiang, C. (2008). SARS coronavirus entry into host cells through a novel clathrin- and caveolae-independent endocytic pathway. Cell Research, 18(2), 290-301. https://doi.org/10.1038/cr.2008.15

Wang, J., Hajizadeh, N., Moore, E. E., McIntyre, R. C., Moore, P. K., Veress, L. A., ... Barrett, C. D. (2020). Tissue Plasminogen Activator (tPA) Treatment for COVID-19 Associated Acute Respiratory Distress Syndrome 
(ARDS): A Case Series. Journal of Thrombosis and Haemostasis. https://doi.org/10.1111/jth.14828

Wang, M., Cao, R., Zhang, L., Yang, X., Liu, J., Xu, M., ... Xiao, G. (2020). Remdesivir and chloroquine effectively inhibit the recently emerged novel coronavirus (2019-nCoV) in vitro. Cell Research, 30(3), 269-271. https://doi.org/10.1038/s41422-020-0282-0

Wei, W. E., Li, Z., Chiew, C. J., Yong, S. E., Toh, M. P., \& Lee, V. J. (2020). Presymptomatic Transmission of SARS-CoV-2-Singapore. Morbidity and Mortality Weekly Report, 69(14), 411-415.

Wenzhong, Liu, \& Hualan, L. (2020). COVID-19: Attacks the 1-Beta Chain of Hemoglobin and Captures the Porphyrin to Inhibit Human Heme Metabolism. https://doi.org/10.26434/CHEMRXIV.11938173.V8

WHO Stops Study Of Experimental Drug Hydroxychloroquine: Coronavirus Live Updates: NPR. (n.d.). Retrieved May 28, 2020, from https://www.npr.org/sections/coronavirus-live-updates/2020/05/25/861913688/who-halts-hydroxychloroqui ne-trial-over-safety-concerns

Wong, C. K., Lam, C. W. K., Wu, A. K. L., Ip, W. K., Lee, N. L. S., Chan, I. H. S., ... Sung, J. J. Y. (2004). Plasma inflammatory cytokines and chemokines in severe acute respiratory syndrome. Clinical and Experimental Immunology, 136(1), 95-103. https://doi.org/10.1111/j.1365-2249.2004.02415.x

Woo, P. C. Y., Huang, Y., Lau, S. K. P., \& Yuen, K. Y. (2010). Coronavirus genomics and bioinformatics analysis. Viruses, 2(8), 1805-1820. https://doi.org/10.3390/v2081803

Wrapp, D., Wang, N., Corbett, K. S., Goldsmith, J. A., Hsieh, C. L., Abiona, O., ... McLellan, J. S. (2020). Cryo-EM structure of the 2019-nCoV spike in the prefusion conformation. Science, 367(6483), 1260-1263. https://doi.org/10.1126/science.aax0902

Wu, F., Zhao, S., Yu, B., Chen, Y. M., Wang, W., Song, Z. G., ... Zhang, Y. Z. (2020). A new coronavirus associated with human respiratory disease in China. Nature, 579(7798), 265-269. https://doi.org/10.1038/s41586-020-2008-3

Wu, J. T., Leung, K., \& Leung, G. M. (2020). Nowcasting and forecasting the potential domestic and international spread of the 2019-nCoV outbreak originating in Wuhan, China: a modelling study. The Lancet, 395(10225), 689-697. https://doi.org/10.1016/S0140-6736(20)30260-9

Xiao, F., Tang, M., Zheng, X., Liu, Y., Li, X., \& Shan, H. (2020). Evidence for Gastrointestinal Infection of SARS-CoV-2. Gastroenterology, 158(6), 1831-1833.e3. https://doi.org/10.1053/j.gastro.2020.02.055

Xu, X., Han, M., Li, T., Sun, W., Wang, D., Fu, B., ... Wei, H. (2020). Effective Treatment of Severe COVID-19 Patients with Tocilizumab. ChinaXiv, 117(20), 1-12. https://doi.org/10.1073/pnas.2005615117

Xu, Z., Shi, L., Wang, Y., Zhang, J., Huang, L., Zhang, C., ... Wang, F. S. (2020). Pathological findings of COVID-19 associated with acute respiratory distress syndrome. The Lancet Respiratory Medicine, 8(4), 420-422. https://doi.org/10.1016/S2213-2600(20)30076-X

Yeo, C., Kaushal, S., \& Yeo, D. (2020). Enteric involvement of coronaviruses: is faecal-oral transmission of SARS-CoV-2 possible? The Lancet Gastroenterology and Hepatology, 5(4), 335-337. https://doi.org/10.1016/S2468-1253(20)30048-0

Zhang, C., Wu, Z., Li, J. W., Zhao, H., \& Wang, G. Q. (2020). The cytokine release syndrome (CRS) of severe COVID-19 and Interleukin-6 receptor (IL-6R) antagonist Tocilizumab may be the key to reduce the mortality. International Journal of Antimicrobial Agents, 55. https://doi.org/10.1016/j.ijantimicag.2020.105954

Zhang, X. W., \& Yap, Y. L. (2004). Structural similarity between HIV-1 gp41 and SARS-CoV S2 proteins suggests an analogous membrane fusion mechanism. Journal of Molecular Structure: THEOCHEM, 677(1-3), 73-76. https://doi.org/10.1016/j.theochem.2004.02.018

Zhou, P., Yang, X. Lou, Wang, X. G., Hu, B., Zhang, L., Zhang, W., ... Shi, Z. L. (2020). A pneumonia outbreak associated with a new coronavirus of probable bat origin. Nature, 579(7798), 270-273. https://doi.org/10.1038/s41586-020-2012-7

Zhu, N., Zhang, D., Wang, W., Li, X., Yang, B., Song, J., .. Tan, W. (2020). A novel coronavirus from patients with pneumonia in China, 2019. New England Journal of Medicine, 382(8), 727-733. https://doi.org/10.1056/NEJMoa2001017 


\section{Copyrights}

Copyright for this article is retained by the author(s), with first publication rights granted to the journal.

This is an open-access article distributed under the terms and conditions of the Creative Commons Attribution license (http://creativecommons.org/licenses/by/4.0/). 